\title{
FAKTOR-FAKTOR YANG MEMPENGARUHI PERTUMBUHAN LABA BANK UMUM SYARIAH DI INDONESIA
}

\author{
Yani Suryani $a^{*}$, Desi Ika $a$ \\ ${ }^{a}$ Fakultas Ekonomi dan Bisnis, Universitas Harapan Medan
}

Diterima Juni 2019; Disetujui Agustus 2019; Dipublikasikan November 2019

\begin{abstract}
Abstrak
Penelitian ini bertujuan untuk mengetahui pengaruh variabel determinan atas pertumbuhan laba pada bank umum syariah di Indonesia. Selama periode krisis finansial pada tahun 1997 bank syariah masih dapat menunjukkan kinerja yang relatif lebih baik dibandingkan dengan lembaga perbankan konvensional. dikarenakan lebih rendahnya penyaluran pembiayaan yang bermasalah (non performing loans) pada bank syariah dan tidak terjadinya negative spread dalam kegiatan operasionalnya serta pertumbuhan laba yang dihasilkan oleh bank syariah. Penelitian ini menganalisis pengaruh Net Operational Income (NOI), Dana Pihak Ketiga (DPK), Capital Adequacy Ratio (CAR), Non Performing Financing (NPF), Financing to Deposit Ratio (FDR), dan Biaya operasional terhadap pendapatan operasional (BOPO) baik secara parsial maupun secara simultan terhadap Pertumbuhan Laba bank umum syariah di Indonesia periode 2016-2018. Adapun jenis penelitian ini asosiatif, sumber data sekunder dan data dianalisis secara kuantitatif. Hasil penelitian ini menunjukkan bahwa secara parsial Net Operating Income (NOI) berpengaruh terhadap pertumbuhan laba Bank Umum Syariah di Indonesia. Untuk pengujian secara simultan keseluruhan variabel determinan tidak berpengaruh terhadap pertumbuhan laba pada Bank Umum Syariah di Indonesia.
\end{abstract}

Kata Kunci : Pertumbuhan laba, Bank Syariah, Non Performing Loans

\begin{abstract}
This study aims to know the effect of the determinant variables on profit growth in Islamic commercial banks in Indonesia. During the period of financial crisis in 1997 Islamic banks were still able to show relatively better performance compared to conventional banking institutions. Due to the lower distribution of non-performing loans (non-performing loans) to the Islamic banks and no negative spreads in their operational activities, this condition as well as profit growth generated by Islamic banks. This study analyzes the effect of Net Operational Income (NOI), Third Party Funds (DPK), Capital Adequacy Ratio (CAR), Non Performing Financing (NPF), Financing to Deposit Ratio (FDR), and operational costs to operational income (BOPO) both partially or simultaneously on the Profit Growth of Islamic commercial banks in Indonesia in the 2016-2018 period. The type of research is associative, secondary data sources and data are analyzed quantitatively. The results of this study indicate that partially Net Operating Income (NOI) affects the profit growth of Islamic Commercial Banks in Indonesia. For simultaneous testing the overall determinant variable does not affect earnings growth at Islamic Commercial Banks in Indonesia.
\end{abstract}

Keyword: Growth Profit, Sharia Bank, Non Performing Loans

How To Cite: Suryani, Yani \& Ika, Desi (2019) Faktor-Faktor Yang Mempengaruhi Pertumbuhan Laba Bank Umum Syariah Di Indonesia. Jurnal Akuntansi dan Bisnis: Jurnal Program Studi Akuntansi, 5 (2): 115 - 128

* email: svani91@vahoo.co.id 


\section{PENDAHULUAN}

Karakteristik sistem perbankan syariah yang beroperasi berdasarkan prinsip bagi hasil memberikan alternatif sistem perbankan yang saling menguntungkan bagi masyarakat dan bank, serta menonjolkan aspek keadilan dalam bertansaksi, investasi yang beretika, mengedepankan nilai-nilai kebersamaan dan persaudaraan dalam berproduksi, dan menghindari kegiatan spekulatif dalam bertransaksi keuangan (Latumaerissa, 2011). Perbankan syariah sebagai sub sistem Ekonomi Islam mempunyai perbedaan prinsip dengan perbankan konvensional. Pada perbankan syariah, setiap transaksi dalam berbagai bidang kehidupan termasuk dalam kegiatan ekonomi harus dilakukan secara transparan dan adil atas dasar saling menguntungkan tanpa paksaan dari pihak manapun, serta mendapatkan laba dari perolehan bagi hasil (Machmud \& Rukmana, 2010). Bank syariah dalam menjalankan operasinya tidak menggunakan sistem bunga sebagai dasar untuk menentukan imbalan yang akan diterima atas jasa pembiayaan yang diberikan, demikian pula imbalan yang akan diberikan kepada nasabah atas dana yang dititipkan kepada bank.

Kegiatan perbankan di Indonesia mengalami pasang surut. Krisis finansial pada tahun 1997 merupakan bukti merosotnya kondisi perbankan di Indonesia (Adnan, M. A., \& Taufiq, M. I. 2001), ditandai dengan penurunan nilai tukar rupiah dan dilikuidasinya beberapa bank konvensional oleh Bank Indonesia (Machmud \& Rukmana, 2010). Selama periode krisis ekonomi tersebut, bank syariah masih dapat menunjukkan kinerja yang relatif lebih baik dibandingkan dengan lembaga perbankan konvensional. Hal ini dapat dilihat dari relatif lebih rendahnya penyaluran pembiayaan yang bermasalah (non performing loans) pada bank syariah dan tidak terjadinya negative spread dalam kegiatan operasionalnya. Hal tersebut dapat dipahami mengingat tingkat pengembalian pada bank syariah tidak mengacu pada tingkat suku bunga (interest spread based) tetapi pada prinsip profit and loss sharing (bagi hasil) dan pada akhirnya dapat menyediakan dana investasi dengan biaya modal yang relatif lebih rendah kepada masyarakat (Soemitra, 2016).

Volume usaha perbankan syariah dalam kurun waktu satu tahun terakhir, khususnya Bank Umum Syariah (BUS) dan Unit Usaha Syariah (UUS), mengalami pertumbuhan yang sangat pesat. Market share perbankan syariah terhadap perbankan nasional telah mencapai sekitar 3,8\%. Tingginya pertumbuhan aset tersebut tidak terlepas dari tingginya pertumbuhan dana pihak ketiga pada sisi pasiva dan pertumbuhan penyaluran dana pada sisi aktiva. Penghimpunan dana pihak ketiga meningkat 52,79\% dan penyaluran dana masyarakat meningkat sebesar 46,43\%. (Resmi, 2015). Perkembangan jaringan pelayanan jasa keuangan berbasis syariah tersebut dapat mengidentifikasikan tingginya kebutuhan/ permintaan masyarakat terhadap pelayanan jasa keuangan berdasar prinsip syariah. Dalam rangka memperebutkan pasar perbankan di Indonesia dan semakin ketatnya persaingan antara bank syariah dan konvensional, maka bank syariah dituntut memiliki tingkat kesehatan dan kinerja keuangan yang bagus. Hal ini dapat dilihat dari pertumbuhan laba yang dihasilkan oleh bank syariah, pertumbuhan laba yang baik merupakan isyarat kinerja perusahaan yang baik. Akibatnya dari pertumbuhan laba yang baik akan menaikkan nilai perusahaan. Adapun pertumbuhan laba bank syariah dapat dipengaruhi oleh beberapa faktor, diantaranya adalah Net Operational Income (NOI), Pertumbuhan Dana Pihak Ketiga (DPK), Capital Adequacy Ratio (CAR), Non Performing Financing (NPF), Financing to Deposit Ratio (FDR), dan Biaya Operasional Terhadap Pendapatan Operasional (BOPO).

Menurut Undang - Undang Nomor 10. Tahun 1998 tentang perubahan atas UU No. 7 tahun 1992 tentang Perbankan bahwa, bank adalah badan usaha yang menghimpun 
dana dari masyarakat dalam bentuk simpanan dan menyalurkannya kepada masyarakat dalam bentuk kredit dan atau dalam bentuk-bentuk lainnya dalam rangka meningkatkan taraf hidup rakyat banyak. Adapun pada ayat 1 dijelaskan tentang definisi perbankan, perbankan adalah segala sesuatu yang menyangkut tentang bank, mencakup kelembagaan, kegiatan usaha, serta cara dan proses dalam melaksanakan kegiatan usahanya (Fahmi, 2014). Menurut Latumaerissa (2011), bank umum merupakan suatu badan usaha yang kegiatan utamanya menerima simpanan dari masyarakat dan atau pihak lainnya, kemudian mengalokasikannya kembali untuk memperoleh keuntungan serta menyediakan jasa - jasa dalam lalu lintas pembayaran. Silvanita (2009) juga berargumen bahwa bank adalah anggota lembaga keuangan yang paling dominan, mampu memobilisasi dana, mengumpulkan dan mengalokasikan dana dalam jumlah besar dibandingkan anggota lembaga keuangan lainnya.

Bank merupakan lembaga yang bergerak dalam bidang keuangan, artinya usaha perbankan selalu berkaitan dengan masalah bidang keuangan. Jadi dapat dikaitkan dengan operasionalisasinya bahwa usaha perbankan meliputi tiga kegiatan utama yaitu ; menghimpun dana, menyalurkan dana dan memberikan jasa bank lainnya. Kegiatan menghimpun dan menyalurkan dana merupakan kegiatan pokok perbankan. Sedangkan kegiatan memberikan jasa-jasa bank lainnya hanyalah merupakan pendukung dari kedua kegiatan sebelumnya (Respati, H., \& Yandono, P. E. 2008)..

UU No. 10 Tahun 1998 amandemen UU No. 7 tahun 1992 tentang perbankan dalam Bab II Pasal 3, menyatakan bahwa "fungsi utama perbankan Indonesia adalah sebagai penghimpun dan penyalur dana masyarakat" serta lebih spesifik fungsi bank dapat sebagai :

\section{Agent of Trust}

Dasar utama kegiatan perbankan adalah trust atau kepercayaan, masyarakat bersedia menitipkan dananya di bank apabila dilandasi oleh unsur kepercayaan. Masyarakat percaya bahwa uangnya tidak akan disalahgunakan oleh bank, uangnya akan dikelola dengan baik, bank tidak akan bangkrut, dan juga percaya bahwa pada saat yang telah dijanjikan masyarakat dapat menarik lagi simpanan dananya di bank. Pihak bank sendiri akan menempatkan atau menyalurkan dananya pada debitur atau masyarakat apabila dilandasi unsur kepercayaan. Pihak bank percaya bahwa debitur tidak akan menyalahgunakan pinjamannnya, debitur akan mengelola dana pinjaman dengan baik, debitur akan mempunyai kemampuan untuk membayar pada saat jatuh tempo, dan juga bank percaya bahwa debitur mempunyai niat baik untuk mengembalikan pinjaman beserta kewajiban lainnya pada saat jatuh tempo.

\section{Agent of Development}

Sektor dalam kegiatan perekonomian masyarakat yaitu sektor moneter dan sektor riil, tidak dapat dipisahkan. Kedua sektor tersebut berinteraksi saling mempengaruhi satu dengan yang lain. Sektor riil tidak akan dapat berkinerja dengan baik apabila sektor moneter tidak bekerja dengan baik. Tugas bank sebagai penghimpun dan penyalur dana sangat diperlukan untuk kelancaran kegiatan perekonomian di sektor riil. Kegiatan bank tersebut memungkinkan masyarakat melakukan investasi, distribusi dan juga konsumsi barang dan jasa, mengingat semua kegiatan investasi-distribusi-konsumsi selalu berkaitan dengan penggunaan uang. Kelancaran kegiatan investasi-distribusi-konsumsi ini tidak lain adalah kegiatan pembangunan perekonomian masyarakat.

\section{Agent of Services}

Di samping melakukan kegiatan penghimpunan dan penyaluran dana, bank juga memberikan penawaran jasa-jasa perbankan yang lain kepada masyarakat. Jasa-jasa yang ditawarkan bank ini erat kaitannya dengan kegiatan perekonomian masyarakat 
secara umum. Jasa-jasa bank ini antara lain dapat berupa jasa pengiriman uang, jasa penitipan barang berharga, jasa pemberian jaminan bank dan jasa penyelesaian tagihan. Sedangkan tujuan bank dalam UU No. 7 tahun 1992 tentang perbankan Bab III pasal 4, menyatakan bahwa : "Perbankan Indonesia bertujuan menunjang pelaksanaan pembangunan masyarakat dalam rangka pemerataan, pertumbuhan ekonomi, dan stabilitas nasional ke arah peningkatan kesejahteraan rakyat banyak."

Adapun menurut UU No. 7 Tahun 1993 tentang perbankan, Bank Umum Syariah (Bank bagi hasil) adalah bank yang dalam aktivitasnya tidak menarik bunga dari jasa usahanya, tetapi diperhitungkan mendapat bagian jasa berupa bagi hasil. kemudian dipertegas kembali dengan PP No72 tahun 1992 tentang bank dengan sistem bagi hasil. Sesuai Undang - Undang tersebut maka sesuai dengan Undang - Undang No. 10 tahun 1998, bank juga wajib memelihara kesehatannya. Kesehatan Bank yang merupakan ceminan kondisi dan kinerja bank merupakan sarana bagi otoritas pengawas dalam menetapkan strategi dan fokus tehadap pengawasan bank. Selain itu, kesehatan bank juga menjadi kepentingan semua pihak yang terkait, baik pemilik, pengelola (manajemen) dan masyarakat pengguna jasa bank.

\section{Net Operating Income (NOI)}

Net Operating Income adalah rasio pendapatan bagi hasil dengan rata - rata aktiva produktif. Pendapatan diperoleh dari bagi hasil yang diterima dari pinjaman yang diterima dikurangi dengan biaya bagi hasil dari sumber dana yang dikumpulkan. NOI suatu bank sehat bila memiliki NOI di atas $2 \%$ (Muljono, 1999). Rasio ini mengukur kemampuan bank dalam mengelola aktiva produktif untuk menghasilkan pendapatan bunga dari kegiatan operasional bank. Pendapatan bagi hasil bersih merupakan pendapatan bagi hasil (beban bagi hasil dan komisi provisi).

\section{Dana Pihak Ketiga (DPK)}

Di dalam terminologi syariah, simpanan (Dana Pihak Ketiga / DPK) dikenal dengan al wadiah yang diartikan sebagai titipan murni dari suatu pihak kepada pihak lain, baik individu maupun badan hukum yang harus dijaga dan dikembalikan kapan saja atas kehendak penyimpan (nasabah) (Silvanita, 2009). Menurut Undang - Undang Perbankan Republik Indonesia No. 10 Tahun 1998 tentang Perbankan, Dana Pihak Ketiga (Simpanan) adalah Dana yang dipercayakan oleh masyarakat kepada bank berdasarkan perjanjian penyimpanan dana dalam bentuk giro, deposito, sertifikat deposito, tabungan dan atau bentuk lainnya yang dipersamakan dengan itu. Sedangkan Dana Pihak Ketiga adalah Dana yang berasal dari masyarakat luas yang merupakan sumber dana terpenting bagi kegiatan operasional suatu bank dan merupakan ukuran keberhasilan bank jika mampu membiayai operasionalnya dari sumber dana ini. (Kashmir, 2008; Sariasih, N. W., \& Dewi, M. R. 2014). Menurut PAPSI tahun 2013, Simpanan adalah kewajiban bank kepada pihak ketiga (bukan bank) berupa giro dan tabungan yang menggunakan prinsip wadiah. Wadiah adalah titipan nasabah yang harus dijaga dan dikembalikan setiap saat bila nasabah yang bersangkutan menghendaki. Bank bertanggung jawab atas pengembalian tersebut. Prinsip simpanan murni (al - wadiah) merupkan fasilitas yang diberikan oleh bank Islam untuk memberikan kesempatan kepada pihak yang kelebihan dana untuk menyimpan dananya dalam bentuk al - wadiah. Fasilitas al - wadiah biasanya diberikan untuk tujuan investasi guna mendapatkan keuntungan seperti tabungan dan deposito. Dalam dunia perbankan konvensional al - wadiah identik dengan giro. 


\section{Financing to Deposit Ratio (FDR)}

Pengertian Financing to Deposit Ratio (FDR) adalah rasio pembiayaan terhadap total dana pihak ketiga, yang menggambarkan perbandingan pembiayaan yang disalurkan dengan jumlah DPK (Muhammad, 2005). Financing to Deposit Ratio (FDR) dalam perbankan konvensional sering disebut dengan Loan to Deposit Ratio (LDR) menunjukkan kesehatan bank dalam memberikan pembiayaan atau merupakan suatu pengukuran tradisional yang menunjukkan deposito berjangka, giro, tabungan dan lain lain yang digunakan dalam memenuhi permohonan pinjaman nasabahnya. Rasio ini menggambarkan sejauh mana simpanan digunakan untuk pemberian pinjaman. Rasio ini juga dapat mengukur tingkat likuiditas. Rasio yang tinggi menunjukkan bahwa suatu bank memberikan pinjaman seluruh dananya atau relatif tidak likuid. Sebaliknya rasio yang rendah menunjukkan bank yang likuid dengan kelebihan kapasitas dana yang siap untuk dipinjamkan (Latumaerissa, 2011).

\section{Non Performing Finance (NPF)}

Non Performing Finance (NPF) menunjukkan perbandingan kredit kurang lancar, diragukan dan macet dengan total Kredit (Latumaerissa, 2011). Seperti diketahui Non Performing Finance (NPF) merupakan salah satu indikator tingkat kesehatan bank umum, sebab tingginya NPF merupakan ketidakmampuan bank umum dalam proses penilaian sampai dengan pencairan kredit kepada debitur. Di sisi lain NPF juga menyebabkan tingginya biaya modal (Cost of Capital) yang tercermin dari biaya operasional bank tersebut. Dengan tingginya biaya modal maka akan berpengaruh terhadap perolehan laba bersih dari bank.

\section{Permodalan (Capital Adequacy Ratio / CAR)}

Penilaian atas faktor permodalan meliputi penilaian terhadap tingkat kecukupan permodalan dan pengelolaan permodalan. Penilaian terhadap tingkat kecukupan permodalan adalah dengan menggunakan Capital Adequacy Ratio (CAR). Menurut Fahmi, (2014) Capital Adequacy Ratio (CAR) atau sering disebut dengan istilah rasio kecukupan modal bank, yaitu bagaimana sebuah bank mampu membiayai aktivitas kegiatannya dengan kepemilikan modal yang dimilikinya. Dengan kata lain, Capital Adequacy Ratio adalah rasio kinerja bank untuk mengukur kecukupan modal yang dimiliki bank untuk menunjang aktiva yang mengandung atau menghasilkan risiko, misalnya kredit yang diberikan. Semakin tinggi CAR, menunjukkan tingkat kecukupan permodalan perusahaan perbankan besar sehingga mampu menghasilkan laba yang besar dan dapat meningkatkan pertumbuhan laba.

\section{Rasio Biaya Operasional Terhadap Pendapatan Operasional (BOPO)}

BOPO merupakan rasio biaya operasional per pendapatan operasional, yang menjadi proxy efisiensi operasional seperti yang biasa digunakan oleh Bank Indonesia. Semakin efisiensi kinerja operasional suatu bank maka keuntungan yang diperoleh akan semakin besar. Bagi manajemen bank, hal ini menunjukkan pentingnya memperhatikan biaya sehingga dapat menghasilkan rasio BOPO yang sesuai dengan ketentuan yang ditetapkan oleh otoritas moneter (Kuncoro \& Suhardjono, 2002). Selanjutnya Siamat (2005) mengemukakan bahwa dalam usaha perbankan dihadapkan oleh berbagai macam risiko dalam menjalankan operasionalnya. Risiko yang dihadapi bank seperti ; risiko kredit, risiko investasi, risiko perasional dan risiko penyelewengan. Kemudian BOPO merupakan upaya bank untuk meminimalkan risiko operasional, yang merupakan 
ketidakpastian mengenai kegiatan usaha bank tersebut. Risiko operasional kemungkinan berasal dari kerugian operasional bila terjadi penurunan keuntungan yang dipengaruhi oleh struktur biaya operasional bank, dan kemungkinan terjadinya kegagalan atas jasa jasa dan produk - produk yang ditawarkan.

\section{Pertumbuhan Laba}

Ghozali dan Chariri (2007) menjustifikasi laba adalah kenaikan manfaat ekonomi selama satu periode akuntansi dalam bentuk pemasukan atau penambahan aset atau penurunan kewajiban yang mengakibatkan kenaikan ekuitas yang tidak berasal dari kontribusi peranan modal. Laba merupakan indikator efisiensi penggunaan dana perusahaan, dasar dalam penilaian prestasi atau kinerja manajemen perusahaan, sebagai alat motivasi manajemen dan alat pengendalian alokasi sumber daya ekonomi, dasar dalam peramalan laba maupun kejadian ekonomi perusahaan lainnya di masa yang akan datang, dasar dalam perhitungan kenaikan kemakmuran perusahaan, dasar dalam perhitungan pajak, dasar kompensasi dan pembagian bonus, serta dasar pembagian dividen. Pertumbuhan laba adalah persentase kenaikan laba yang diperoleh perusahaan. Pertumbuhan laba dihitung dengan cara mengurangkan laba periode sekarang dengan laba periode sebelumnya kemudian dibagi dengan laba pada periode sebelumnya. Usman (2003) menyatakan pertumbuhan laba merupakan selisih laba tahun ini dengan laba bersih tahun lalu dibagi laba bersih tahun lalu, dihitung dengan cara mengurangkan laba periode sekarang dengan laba periode sebelumnya kemudian dibagi dengan laba periode sebelumnya. Sedangkan menurut Cahyaningrum (2012), laba secara operasional merupakan perbedaan antara pendapatan yang direalisasi yang timbul dari transaksi selama satu periode dengan biaya yang berkaitan dengan pendapatan tersebut.

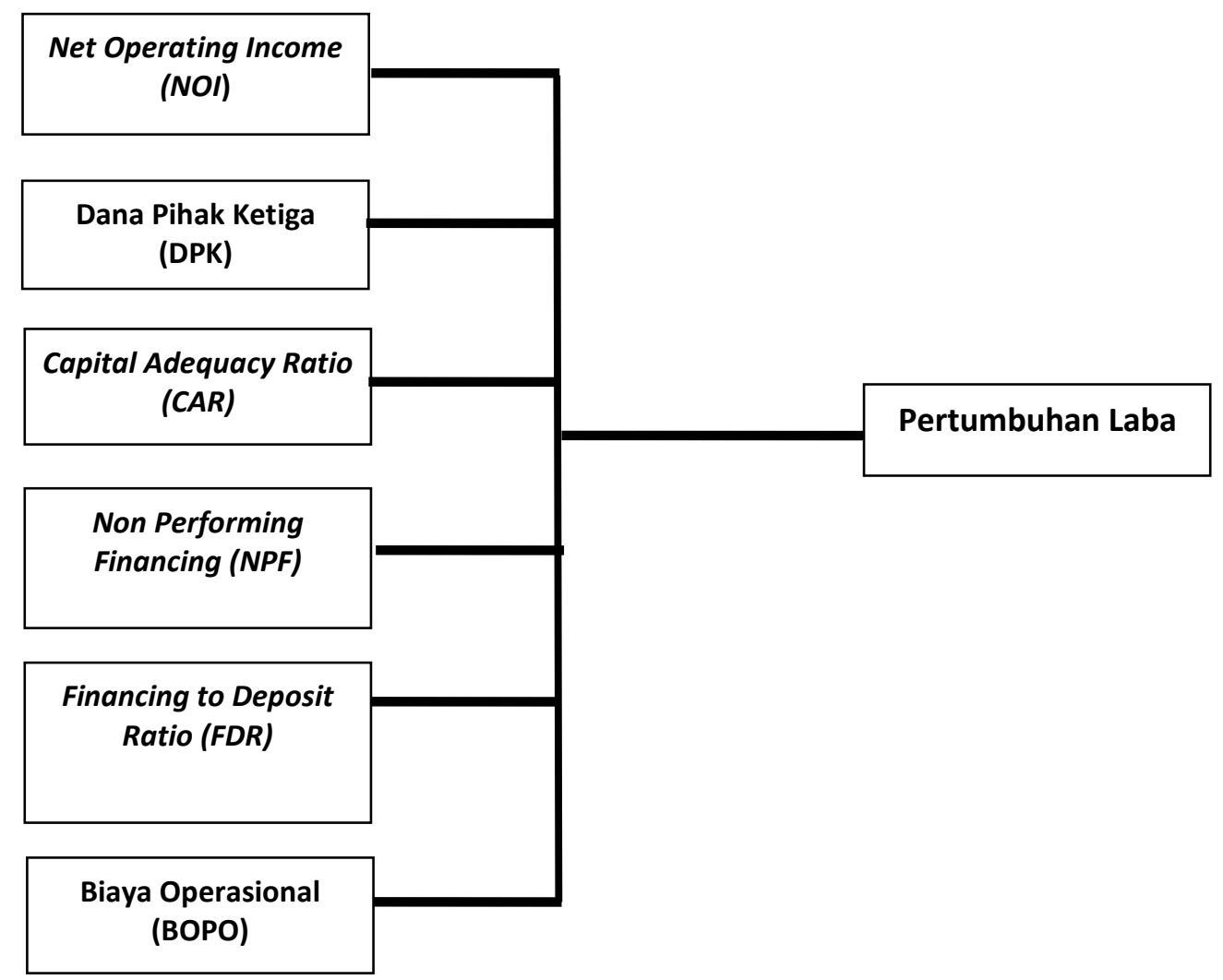

Gambar 1 Kerangka Konseptual 
Berdasarkan uraian tersebut di atas, selanjutnya dapat dibuat hipotesis penelitian sebagai berikut :

$\mathrm{H}_{1} \quad$ : Net Operating Income (NOI) berpengaruh terhadap pertumbuhan laba pada Bank Umum Syariah di Indonesia

$\mathrm{H}_{2} \quad$ : $\quad$ Dana Pihak Ketiga berpengaruh terhadap pertumbuhan laba bank Umum Syariah di Indonesia

$\mathrm{H}_{3} \quad$ : $\quad$ Capital Adequacy Ratio (CAR) berpengaruh terhadap pertumbuhan laba pada Bank Umum Syariah di Indonesia

H4 : Non Performing Finance (NPF) berpengaruh terhadap pertumbuhan laba pada Bank Umum Syariah di Indonesia

H5 : Finance to Deposit Ratio (FDR) berpengaruh terhadap pertumbuhan laba Bank Umum Syariah di Indonesia.

H6 : BOPO berpengaruh terhadap pertumbuhan laba Bank Umum Syariah di Indonesia

H7 : NOI, DPK, CAR, NPF, FDR dan BOPO berpengaruh terhadap pertumbuhan laba Pada Bank Umum Syariah di Indonesia.

\section{METODE PENELITIAN}

\section{Jenis dan Lokasi Penelitian}

Jenis penelitian yang digunakan dalam penelitian ini adalah penelitian yang menggunakan metode asosiatif. Penelitian ini menganalisis faktor-faktor yang mempengaruhi pertumbuhan laba bank umum syariah di Indonesia. Data sekunder yang digunakan diperoleh melalui laporan keuangan tahun 2016-2018 yang dipublikasikan oleh Bursa Efek Indonesia.

\section{Pengambilan Sampel}

Populasi adalah jumlah dari keseluruhan objek yang karakteristiknya hendak diduga. Populasi dalam penelitian ini adalah seluruh bank umum syariah yang beroperasi di Indonesia periode 2016 - 2018. Populasi dalam penelitian terdiri dari 13 bank umum syariah. Sampel adalah sebagian dari populasi yang karakteristiknya hendak diselidiki dan dianggap bisa mewakili dari keseluruhan populasi. Sampel yang digunakan dalam penelitian ini ditentukan dengan menggunakan teknik purposive sampling, yaitu teknik penentuan sampel dengan pertimbangan tertentu (Sugiyono, 2008). Teknik penarikan sampel dalam penelitian ini menggunakan metode Purposive Sampling. Metode Purposive Sampling adalah metode penentuan sampel dengan berdasarkan atas kriteria-kriteria tertentu. Adapun kriteria yang digunakan dalam penelitian ini adalah sebagai berikut ; bank umum syariah yang beroperasi di Indonesia dan terdaftar di Otoritas Jasa Keuangan, bank umum syariah yang menerbitkan laporan keuangan tahunan lengkap pada periode penelitian yaitu tahun 2016 -2018, jumlah Bank Umum Syariah di Indonesia adalah 13 Bank Umum Syariah dan yang tidak memenuhi kriteria adalah PT Bank Panin Syariah. Berdasarkan kriteria yang dikemukakan di atas, maka diperoleh 12 Bank Umum Syariah yang memenuhi kriteria untuk dijadikan sebagai sampel penelitian.

\section{Teknik Analisa Data}

Penelitian ini dilakukan dengan lebih dulu melakukan uji asumsi klasik untuk mengetahui bahwa model terbebas dari masalah normalitas data, multikolinieritas, 
autokorelasi dan heteroskedastisitas. Teknik analisa data yang digunakan adalah teknik analisis regresi linier berganda.

\section{Definisi Operasional Variabel}

Untuk menjelaskan variabel-variabel yang sudah diidentifikasi, maka operasional variabel terdapat pada tabel 1 berikut.

Tabel 1 Operasionalisasi Variabel

\begin{tabular}{|c|c|c|c|}
\hline Variabel & Definisi & Indikator & Skala \\
\hline $\begin{array}{l}\text { Pertumbuhan } \\
\text { Laba (Y) }\end{array}$ & $\begin{array}{l}\text { Persentase kenaikan laba yang } \\
\text { diperoleh perusahaan. } \\
\text { Pertumbuhan laba yang baik } \\
\text { merupakan isyarat kinerja } \\
\text { perusahaan yang baik. Akibat } \\
\text { dari pertumbuhan laba yang } \\
\text { baik akan menaikkan nilai } \\
\text { perusahaan. }\end{array}$ & $\begin{array}{l}\text { Persentase jumlah pengurangan } \\
\text { laba tahun } t \text { dengan tahun } t-1 \\
\text { yang dibandingkan dengan laba } \\
\text { pada tahun } t-1 \text {. }\end{array}$ & Rasio \\
\hline $\begin{array}{l}\text { Net } \\
\text { Operational } \\
\text { Income (NOI) }\end{array}$ & $\begin{array}{l}\text { Rasio ini mengukur kemampuan } \\
\text { bank dalam mengelola aktiva } \\
\text { produktif untuk menghasilkan } \\
\text { pendapatan bunga dari kegiatan } \\
\text { operasional bank. }\end{array}$ & $\begin{array}{l}\text { NOI = Pendapatan bagi hasil / rata- } \\
\text { rata aktiva produktif x } 100 \%\end{array}$ & Rasio \\
\hline $\begin{array}{l}\text { Dana Pihak } \\
\text { Ketiga }(\mathrm{DPK})\end{array}$ & $\begin{array}{l}\text { Dana yang dihimpun bank dari } \\
\text { masyarakat pada bank } \\
\text { berdasarkan danjian } \\
\text { penyimpanan dana dalam } \\
\text { bentuk giro, deposito, tabungan, } \\
\text { sertifikat deposito dan atau } \\
\text { bentuk lainnya yang } \\
\text { dipersamakan dengan itu. }\end{array}$ & $\begin{array}{l}\text { Dana Masyarakat = Jumlah Dana } \\
\text { Masyarakat (jutaan rupiah) }\end{array}$ & Rasio \\
\hline $\begin{array}{l}\text { Capital } \\
\text { Adequacy } \\
\text { Ratio (CAR) }\end{array}$ & $\begin{array}{l}\text { Rasio yang memperlihatkan } \\
\text { seberapa besar jumlah seluruh } \\
\text { aktiva bank yang mengandung } \\
\text { unsur risiko (kredit, penyertaan, } \\
\text { surat berharga, tagihan pada } \\
\text { bank lain) yang ikut dibiayai } \\
\text { dari modal sendiri di samping } \\
\text { memperoleh dana-dana dari } \\
\text { sumber- sumber di luar bank. }\end{array}$ & $\mathrm{CAR}=\frac{\text { Modal }}{\mathrm{ATMR}} \times 100 \%$ & Rasio \\
\hline $\begin{array}{l}\text { Non } \\
\text { Performing } \\
\text { Financing } \\
(N P F)\end{array}$ & $\begin{array}{l}\text { Perbandingan } \\
\text { pembiayaan } \text { bermasalah dan } \\
\text { pembiayaan yang disalurkan } \\
\text { oleh bank. }\end{array}$ & $\mathrm{NPF}=\frac{\text { Pembiayaan KLDM }}{\text { Total Pembiayaan }} \times 100 \%$ & Rasio \\
\hline $\begin{array}{l}\text { Financing to } \\
\text { Deposit Ratio } \\
(F D R)\end{array}$ & $\begin{array}{l}\text { Perbandingan antara } \\
\text { pembiayaan yang diberikan oleh } \\
\text { bank dengan dana pihak ketiga } \\
\text { yang berhasil dikerahkan oleh } \\
\text { bank. }\end{array}$ & $(F D R)=\frac{\text { Total Pembiayaan }}{\text { Total DPK }}$ & Rasio \\
\hline $\begin{array}{l}\text { Biaya } \\
\text { Operasional } \\
\text { terhadap } \\
\text { Pendapatan } \\
\text { Operasional } \\
\text { (BOPO) }\end{array}$ & $\begin{array}{lr}\text { Rasio efisiensi yang digunakan } \\
\text { untuk mengukur kemampuan } \\
\text { manajemen bank dalam } \\
\text { mengendalikan } & \text { biaya } \\
\text { operasional } & \text { terhadap } \\
\text { pendapatan operasional. }\end{array}$ & BOPO $=\frac{\text { Belanja Operasional }}{\text { Pendapatan Operasional }} \times 100 \%$ & Rasio \\
\hline
\end{tabular}




\section{HASIL DAN PEMBAHASAN}

\section{Statistik Deskriptif}

Statistik deskriptif berfungsi untuk mendeskripsikan atau memberi gambaran terhadap obyek yang diteliti melalui data sampel sebagaimana adanya, tanpa melakukan analisis dan membuat kesimpulan yang berlaku untuk umum. Gambaran atau deskripsi suatu data dapat dilihat dari nilai rata-rata (mean), standar deviasi, maksimum dan minimum. Berikut adalah statistik deskriptif yang diperoleh dari data yang diolah dengan menggunakan SPSS (Statistical Package for the Social Sciences) dapat dilihat pada Tabel 2 berikut :

Tabel 2 Descriptive Statistics

\begin{tabular}{cccccc}
\hline & $\mathrm{N}$ & Minimum & Maximum & Mean & Std. Deviation \\
\hline PL & 36 & 1.57 & 144.00 & 41.8883 & 33.07580 \\
NOI & 36 & .16 & 24.96 & 6.8864 & 5.12874 \\
DPK & 36 & 70.00 & 62113.00 & $1.5160 \mathrm{E} 4$ & 17842.82966 \\
CAR & 36 & 12.00 & 55.06 & 21.5847 & 10.45600 \\
NPF & 36 & .07 & 17.91 & 3.1950 & 3.13743 \\
FDR & 36 & 9.38 & 157.77 & 92.4828 & 20.38859 \\
BOPO & 36 & 7.76 & 192.60 & 92.3431 & 34.96759 \\
\hline
\end{tabular}

Berdasarkan tabel 2 di atas menunjukkan jumlah data sampel (N) sebanyak 36 yang terdiri dari 12 perusahaan sampel dengan 3 tahun pengamatan yaitu tahun 2014 sampai dengan tahun 2016. Adapun variabel yang diteliti adalah variabel independen terdiri dari X1_NOI (Net Operating Income), X2_DPK (Dana Pihak Ketiga), X3_CAR (Capital Adequcy Ratio), X4_NPF (Non Performing Ratio), X5_FDR (Financing to Deposit Ratio) dan X6_BOPO serta variabel dependen Y_PL (Pertumbuhan Laba).

\section{Uji Normalitas}

Pengujian normalitas data yang dilakukan untuk menguji apakah model regresi variabel pengganggu atau residual memiliki distribusi normal. Pengujian ini diperlukan karena untuk melakukan uji t dan uji $\mathrm{F}$ mengasumsikan bahwa nilai residual mengikuti distribusi normal. Jika asumsi ini dilanggar atau tidak dipenuhi maka uji statistik menjadi tidak valid untuk jumlah sampel kecil. Berikut hasil pengujian normalitas dengan menggunakan pendekatan Kolmogorov dan Smirnov dapat dilihat pada Tabel 3 yaitu :

Tabel 3 Uji Normalitas

Kolmogorov-Smirnov Test

\begin{tabular}{ccc} 
& & $\begin{array}{c}\text { Unstandardized } \\
\text { Residual }\end{array}$ \\
\hline \multirow{2}{*}{ Normal Parameters } & Mean & 36 \\
Most Extreme Differences & Std. Deviation & .0000000 \\
& Absolute & 27.96791296 \\
& Positive & .195 \\
Kolmogorov-Smirnov Z & -.075 \\
Asymp. Sig. 2-tailed & 1.168 \\
\end{tabular}


Berdasarkan tabel 3 di atas dapat diketahui nilai Asymp.sig (2-tailed) sebesar 0,131 lebih besar dari nilai $\alpha$ 0,05 yang menunjukkan bahwa variabel residual berdistribusi normal.

\section{Uji Multikolinieritas}

Uji Multikolinieritas bertujuan untuk menguji apakah model regresi ditemukan adanya korelasi antar variabel bebas (independen). Model regresi yang baik seharusnya tidak terjadi korelasi di antara variabel independen. Untuk mendeteksi ada atau tidaknya multikolinieritas di dalam model regresi adalah dilihat dari nilai tolerance dan lawannya variance inflation factor (VIF). Nilai cutoff yang umum dipakai untuk menunjukkan adanya multikolinieritas adalah nilai Tolerance $\leq 0,10$ atau sama dengan nilai VIF $\geq 10$ (Ghozali, 2009: 106). Hasil pengujian dapat dilihat pada Tabel 4 berikut ini :

Tabel 4 Hasil Uji Multikolinieritas

\begin{tabular}{|c|c|c|c|c|c|c|c|}
\hline & \multicolumn{2}{|c|}{$\begin{array}{c}\text { Unstandardized } \\
\text { Coefficients }\end{array}$} & \multirow{2}{*}{$\begin{array}{c}\begin{array}{c}\text { Standardized } \\
\text { Coefficients }\end{array} \\
\text { Beta }\end{array}$} & \multirow[b]{2}{*}{$\mathrm{t}$} & \multirow[b]{2}{*}{ Sig. } & \multicolumn{2}{|c|}{$\begin{array}{c}\text { Collinearity } \\
\text { Statistics }\end{array}$} \\
\hline & B & Std. Error & & & & Tolerance & VIF \\
\hline Constant & -10.591 & 29.142 & & -.363 & .719 & & \\
\hline NOI & 2.794 & 1.091 & .433 & 2.560 & .016 & .861 & 1.162 \\
\hline DPK & .000 & .000 & .104 & .614 & .544 & .867 & 1.154 \\
\hline CAR & .752 & .645 & .238 & 1.167 & .253 & .594 & 1.685 \\
\hline NPF & -.080 & 1.844 & -.008 & -.043 & .966 & .806 & 1.240 \\
\hline FDR & .242 & .330 & .149 & .732 & .470 & .595 & 1.681 \\
\hline BOPO & -.087 & .168 & -.092 & -.517 & .609 & .784 & 1.276 \\
\hline
\end{tabular}

Berdasarkan tabel $4 \mathrm{di}$ atas dapat diketahui nilai tolerance $>0,10$ dan nilai variance inflation factor (VIF) $<10$ yang berarti semua data (variabel) tidak terjadi multikolinieritas.

\section{Uji Heteroskedastisitas}

Pengujian homoskedastisitas pada prinsipnya ingin menguji apakah sebuah grup mempunyai varians yang sama di antara anggota grup tersebut. Jika varians sama, dan ini yang seharusnya terjadi maka dikatakan ada homoskedastisitas. Sedangkan jika varians tidak sama dikatakan terjadi heteroskedastisitas. Untuk mendeteksi adanya heteroskedastisitas dapat dilakukan dengan pendekatan statistik yaitu dengan Uji Glejser. Uji Glejser dilakukan dengan meregres nilai absolut residual terhadap variabel independen. Jika variabel independen signifikan secara statistik mempengaruhi variabel dependen, maka ada indikasi heteroskedastisitas.

Berikut hasil pengujian dengan menggunakan Uji Glejser dapat dilihat pada Tabel 5, berdasarkan Tabel 5 dapat diketahui hasil uji Glejser semua variabel independen tidak signifikan (sig 0,05) terhadap variabel dependen. Hal ini berarti data tidak terkena heteroskedastisitas. 
Tabel 5 Hasil Uji Glejser

\begin{tabular}{ccccccc}
\hline \multicolumn{7}{c}{ Unstandardized } \\
Coefficients & $\begin{array}{c}\text { Standardized } \\
\text { Coefficients }\end{array}$ & & \\
& $\mathrm{B}$ & Std. Error & Beta & $\mathrm{T}$ & Sig. \\
Constant & .005 & .312 & & .015 & .988 \\
NOI & .119 & .086 & .194 & 1.395 & .169 \\
DPK & -.066 & .314 & -.030 & -.209 & .835 \\
CAR & .102 & .108 & .131 & .948 & .348 \\
NPF & .240 & .244 & .132 & .984 & .330 \\
FDR & .242 & .330 & .149 & .732 & .470 \\
BOPO & .087 & .168 & .092 & .517 & .609 \\
\hline
\end{tabular}

\section{Uji Autokorelasi}

Uji Autokorelasi bertujuan menguji apakah dalam model regresi linier ada korelasi antara kesalahan pengganggu pada periode $t$ dengan kesalahan pengganggu pada periode t -1 (sebelumnya). Jika terjadi korelasi, maka dinamakan ada problem autokorelasi. Autokorelasi muncul karena observasi yang berurutan sepanjang waktu berkaitan satu sama lainnya. Salah satu cara untuk mendeteksi ada atau tidaknya autokorelasi adalah dengan menggunakan Uji Durbin - Watson (DW test). Nilai DW akan dibandingkan dengan nilai tabel dengan menggunakan nilai signifikasi 5\% (Ghozali, 2009 : 112). Berikut hasil pengujian Autokorelasi dapat dilihat pada tabel 4.5 yaitu :

Tabel 6 Hasil Uji Autokorelasi

\begin{tabular}{ccccc}
\hline & & Adjusted R & Std. Error of the & \\
$\mathrm{R}$ & R Square & Square & Estimate & Durbin-Watson \\
\hline .534 & .285 & .137 & 30.72523 & 2.172 \\
\hline
\end{tabular}

Berdasarkan tabel 6 di atas dapat diketahui hasil output yang menunjukkan nilai Durbin - Watson sebesar 2,172 atau DW > 2. Keputusan tidak ada autokorelasi positif maupun negatif.

\section{Uji Determinasi $\left(\mathbf{R}^{2}\right)$}

Pengujian koefisien determinan $\left(\mathrm{R}^{2}\right)$ pada intinya mengukur proporsi atau persentase sumbangan variabel bebas yaitu variabel variabel independen terdiri dari X1_NOI (Net Operating Income), X2_DPK (Dana Pihak Ketiga), X3_CAR (Capital Adequcy Ratio), X4_NPF (Non Performing Ratio), X5_FDR (Financing to Deposit Ratio) dan X6_BOPO. terhadap Pertumbuhan Laba (Y) secara bersama-sama, dimana : $0 \leq \mathrm{R}^{2} \leq 1$. Analisis dilakukan dengan melihat nilai Adjusted $R$ Square. Hasil pengujian Determinasi $\left(\mathrm{R}^{2}\right)$ dapat dilihat pada tabel 7 berikut ini :

Tabel 7 Hasil Uji Determinasi $\left(\mathbf{R}^{2}\right)$

\begin{tabular}{cccc}
\hline $\mathrm{R}$ & R Square & $\begin{array}{c}\text { Adjusted R } \\
\text { Square }\end{array}$ & $\begin{array}{c}\text { Std. Error of the } \\
\text { Estimate }\end{array}$ \\
\hline $.534^{\mathrm{a}}$ & .285 & .137 & 30.72523 \\
\hline
\end{tabular}

Berdasarkan tabel 7 di atas dapat diketahui hasil Uji Determinasi atau Goodness of Fit yang menunjukkan nilai $\mathrm{R}$ sebesar 0,534 yang berarti hubungan X1_NOI (Net Operating Income), X2_DPK (Dana Pihak Ketiga), X3_CAR (Capital Adequcy Ratio), X4_NPF 
(Non Performing Ratio), X5_FDR (Financing to Deposit Ratio) dan X6_BOPO. terhadap Pertumbuhan Laba (Y_PL) laba cukup erat dan nilai $R$ Square sebesar 0,285 yang berarti 28,5\% variabel pertumbuhan laba dapat dijelaskan oleh variabel Net Operating Income, Dana Pihak Ketiga, Capital Adequcy Ratio, Non Performing Ratio, Financing to Deposit Ratio dan BOPO. Sedangkan sisanya dapat dijelaskan oleh faktor-faktor lain yang tidak diteliti dalam penelitian ini.

\section{Uji F (Uji Serempak)}

Uji F pada dasarnya menunjukkan apakah semua variabel independen atau bebas yang dimasukkan dalam model mempunyai pengaruh secara bersama - sama terhadap variabel dependen / terikat. Berikut hasil uji F dapat dilihat pada Tabel 8 yaitu :

Tabel 8 Hasil Uji F (Uji Serempak)

\begin{tabular}{cccccc}
\hline \multicolumn{5}{c}{ ANOVA } \\
& $\begin{array}{c}\text { Sum of } \\
\text { Squares }\end{array}$ & df & Square & F & Sig. \\
\hline Regression & 10913.153 & 6 & 1818.859 & 1.927 & $.110^{\text {a }}$ \\
Residual & 27377.145 & 29 & 944.039 & & \\
Total & 38290.298 & 35 & & & \\
\hline
\end{tabular}

Berdasarkan tabel 8 di atas dapat diketahui hasil Uji F (Uji Serempak) yang menunjukkan nilai $\mathrm{F}$ hitung sebesar 1,927 dengan tingkat signifikansi 0,110 pada $\alpha 0,05$. Karena tingkat signifikansinya 0,000 > 0,05 yang berarti variabel Net Operating Income, Dana Pihak Ketiga, Capital Adequcy Ratio, Non Performing Ratio, Financing to Deposit Ratio dan BOPO secara simultan tidak berpengaruh signifikan terhadap pertumbuhan laba.

\section{Uji t (Uji Parsial)}

Uji statistik t pada dasarnya menunjukkan seberapa jauh pengaruh satu variabel penjelas/independen secara individual dalam menerangkan variasi variabel dependen. Hipotesis nol (Ho) yang hendak diuji adalah apakah suatu parameter (bi) sama dengan nol atau Ho : bi = 0 Artinya apakah suatu variabel independen bukan merupakan penjelas yang signifikan terhadap variabel dependen. Hipotesis alternatifnya (Ha) parameter suatu variabel tidak sama dengan nol atau $\mathrm{Ha}$ : bi $\neq 0$ Artinya, variabel tersebut merupakan penjelas yang signifikan terhadap variabel dependen. Kriteria keputusan, jika t hitung $t$ tabel maka Ho diterima atau Ha ditolak, sedangkan jika $t$ hitung t tabel maka Ho ditolak dan Ha diterima. Jika tingkat signifikansi di bawah 0,05 maka Ho ditolak dan Ha diterima. Hasil pengujian secara parsial (Uji t) dapat dilihat pada Tabel 9 berikut, dimana berdasarkan Tabel 9 di atas dapat diketahui dari ke enam variabel yang dimasukkan ke dalam model regesi, variabel Dana Pihak Ketiga (DPK), Capital Adequcy Ratio (CAR), Non Performing Finance (NPF), Financing to Deposit Ratio (FDR) dan BOPO tidak berpengaruh signifikan, hal ini dapat dilihat dari nilai probabilitas signifikansi untuk DPK sebesar 0,544 ; CAR sebesar 0,253 ; NPF sebesar 0.966 ; FDR sebesar 0,470 dan BOPO sebesar 0,609 lebih besar dari $\alpha$ 0,05. Sedangkan variabel $N e t$ Operating Income (NOI) memiliki nilai probabilitas signifikansi 0,016 lebih kecil/berada di bawah $\alpha 0,05$. Hal tersebut menunjukkan variabel NOI berpengaruh terhadap variabel pertumbuhan laba. 
Tabel 9 Hasil Uji t (Uji Parsial)

\begin{tabular}{cccccc}
\hline \multicolumn{7}{c}{$\begin{array}{c}\text { Unstandardized } \\
\text { Coefficients }\end{array}$} & $\begin{array}{c}\text { Standardized } \\
\text { Coefficients }\end{array}$ & & \\
& $\mathrm{B}$ & Std. Error & Beta & $\mathrm{t}$ & Sig. \\
\hline Constant & -10.591 & 29.142 & & -.363 & .719 \\
NOI & 2.794 & 1.091 & .433 & 2.560 & .016 \\
DPK & .000 & .000 & .104 & .614 & .544 \\
CAR & .752 & .645 & .238 & 1.167 & .253 \\
NPF & -.080 & 1.844 & -.008 & -.043 & .966 \\
FDR & .242 & .330 & .149 & .732 & .470 \\
BOPO & -.087 & .168 & -.092 & -.517 & .609 \\
\hline
\end{tabular}

Berdasarkan hasil penelitian di atas melalui Uji Determinasi atau Goodness of Fit dapat diketahui tingkat keeratan hubungan antara variabel independen terhadap variabel dependen yang ditunjukkan dengan nilai $\mathrm{R}$ sebesar 0,534 yang berarti hubungan yang berarti hubungan variabel Net Operating Income (NOI) variabel Dana Pihak Ketiga, Capital Adequcy Ratio, Non Performing Ratio, Financing to Deposit Ratio dan BOPO terhadap pertumbuhan laba cukup erat dan nilai $R$ Square sebesar 0,285 yang berarti 28,5\% variabel pertumbuhan laba dapat dijelaskan oleh variabel Net Operating Income (NOI), Dana Pihak Ketiga (DPK), Capital Adequcy Ratio (CAR), Non Performing Ratio NPR), Financing to Deposit Ratio (FDR) dan BOPO. Sedangkan sisanya dapat dijelaskan oleh faktor - faktor lain yang tidak diteliti dalam penelitian ini. Pengujian secara parsial, variabel Dana Pihak Ketiga (DPK), Capital Adequacy Ratio (CAR), Non Performing Finance (NPF), Financial to Deposit Ratio (FDR) dan Rasio Biaya Operasional dengan Pendapatan Operasional (BOPO) tidak berpengaruh terhadap pertumbuhan laba pada Bank Umum Syariah di Indonesia. Sedangkan variabel Net Operating Income (NOI) berpengaruh terhadap pertumbuhan laba Bank Umum Syariah di Indonesia. Sedangkan secara simultan variabel Net Operating Income (NOI), Dana Pihak Ketiga (DPK), Capital Adequacy Ratio (CAR), Non Performing Finance (NPF), Financial to Deposit Ratio (FDR) dan Rasio Biaya Operasional dengan Pendapatan Operasional (BOPO) tidak berpengaruh terhadap pertumbuhan laba pada Bank Umum Syariah di Indonesia. Hasil penelitian ini tidak sesuai dengan hasil penelitian yang dilakukan oleh Resmi, 2015.

\section{SIMPULAN}

Berdasarkan hasil penelitian di atas, dapat diambil kesimpulan bahwa secara parsial variabel Dana Pihak Ketiga (DPK), Capital Adequacy Ratio (CAR), Non Performing Finance (NPF), Financial to Deposit Ratio (FDR) dan Rasio Biaya Operasional dengan Pendapatan Operasional (BOPO) tidak berpengaruh terhadap pertumbuhan laba pada Bank Umum Syariah di Indonesia. Sedangkan variabel Net Operating Income (NOI) berpengaruh terhadap pertumbuhan laba Bank Umum Syariah di Indonesia. Sedangkan secara simultan variabel Net Operating Income (NOI), Dana Pihak Ketiga (DPK), Capital Adequacy Ratio (CAR), Non Performing Finance (NPF), Financial to Deposit Ratio (FDR) dan Rasio Biaya Operasional dengan Pendapatan Operasional (BOPO) tidak berpengaruh terhadap pertumbuhan laba pada Bank Umum Syariah di Indonesia. 


\section{DAFTAR PUSTAKA}

Adnan, M. A., \& Taufiq, M. I. (2001). Analisis Ketepatan Prediksi Metode Altman terhadap Terjadinya Likuidasi pada Lembaga Perbankan [Kasus Likuidasi Perbankan di Indonesia]. Indonesian Journal of Accounting and Auditing, 5(2), 181-203.

Cahyaningrum, N.H. (2012). Analisis Rasio Keuangan dalam Memprediksi Pertumbuhan Laba (Studi Kasus : Perusahaan Manufaktur yang Terdaftar di Bursa Efek Indonesia Periode 2005 sampai dengan 2010), Tesis, Fakultas Ekonomika dan Bisnis Universitas Diponegoro. Semarang.

Fahmi, M.I.(2014). Pengantar Perbankan Teori dan Aplikasi. Alfabeta. Bandung.

Firdaus, Bambang, (1999). Manajemen Dana Bank. Penerbit Pionir Jaya, Bandung.

Ghozali, Imam. (2009). Ekonometrika: Teori, Konsep dan Aplikasi dengan SPSS 17. Semarang: Badan Penerbit Universitas Dipenogoro.

Ghozali, Imam dan Chariri, Anis (2007), Teori Akuntansi, Semarang: Badan Penerbit UNDIP, Edisi 3.

Kasmir. (2008). Bank dan Lembaga Keuangan Lainnya. Jakarta : Rajawali PT. Raja Grafindo Persada.

Kuncoro, Mudrajad dan Suhardjono (2002), "Manajemen Perbankan, Teori dan Aplikasi”. Edisi Pertama, Fakultas Ekonomi UGM,Yogyakarta

Latumaerissa, J. R. (2011). Bank dan Lembaga Keuangan Lain. Jakarta: Salemba Empat.

Machmud, A. \& Rukmana. (2010). Bank Syariah, Teori, Kebijakan dan Studi Empiris di Indonesia. Jakarta: Erlangga.

Muhammad, HM. S (2005), "Perbankan Syariah dalam Industri Perbankan Nasional”, Jurnal Manajemen Akuntansi dan Bisnis, Vol. 3 no. 1, Jakarta.

Muljono, Teguh Pujo (1999), "Analisa Laporan Keuangan untuk Perbankan”. Edisi Revisi 1999, Jakarta

Respati, H., \& Yandono, P. E. (2008). Tinjauan Tentang Variabel-variabel Camel Terhadap Laba Usaha Pada Bank Umum Swasta Nasional. Jurnal Keuangan dan Perbankan, 12(2), 283-295.

Sariasih, N. W., \& Dewi, M. R. (2014). Pengaruh Dana Pihak Ketiga, Non Performing Loan Dan Inflasi Terhadap Kredit Yang Disalurkan Oleh LPD Kabupaten Badung Periode Tahun 2008-2012. E-Jurnal Manajemen, 3(5).

Siamat, Dahlan (2005), "Manajemen Lembaga Keuangan", Edisi Keempat, Badan Penerbit Fakultas Ekonomi Universitas Indonesia, Jakarta.

Silvanita, K. (2009). Bank Dan Lembaga Keuangan Lain. Erlangga. Jakarta.

Soemitra, A. (2016). Bank dan Lembaga Keuangan Syariah. Jakarta: Kencana.

Sugiyono. (2008). Metode Penelitian Bisnis. Bandung: Alfabeta.

Susilo, S.( 2000). Manajemen Perbankan. Jakarta : PT Raja Grafindo Persada. 